\title{
Australian Journal of

\section{A controlled process of corn sowing as a function of of seed dispensation and working speeds}

\author{
Antonio Tassio Santana Ormond ${ }^{1 *}$, Elizabeth Haruna Kazama ${ }^{1}$, Lucas Augusto da Silva Gírio ${ }^{1}$, Franciele \\ Morlin Carneiro ${ }^{1}$, Murilo Aparecido Voltarelli ${ }^{2}$, Carlos Eduardo Angeli Furlani ${ }^{1}$
}

\author{
${ }^{1}$ Department of Agricultural Engineering, Laboratory of Agricultural Machinery and Mechanization, São Paulo State \\ University, Jaboticabal, São Paulo, Brazil \\ ${ }^{2}$ Federal University of São Carlos, Lagoa do Sino Campus, Buri, SP, Brazil
}

\section{*Corresponding author: tassiormond@gmail.com}

\section{Abstract}

An appropriate sowing process is one of the steps that need immediate attention in crop sciences, because it may compromise the profitability of crops. An effective sowing process requires correctly spaced seedlings with the right depth in order to obtain an appropriate and uniform stand. In this context, statistical control is an option that allows evaluation of the agricultural process. Our objective in this study was to evaluate the quality of maize sowing as a function of planting density and working speeds. The statistical design used was based on the methodology of statistical quality control, corresponding to 4 seed dispensers from different manufacturers denoted DA, DB, DC, and DD with two speeds for each (V1 $=7.0 \mathrm{~km} \mathrm{~h}^{-1}$ and V2 $\left.=11.5 \mathrm{~km} \mathrm{~h}^{-1}\right)$. Data were collected from 10 replicates for each of the 4 seed dispensers, totaling 40 samples, at each working speed. The following parameters were evaluated: Sowing depth, longitudinal distribution of seedlings, initial and final plant population, and corn grain yield for the hybrid $30 \mathrm{~F} 35 \mathrm{YH}$ variety. The statistical process control offers an interesting and reliable mean of evaluating the quality of the sowing process. The seed dispenser, DC, exhibited a better quality of sowing as compared to others. The highest percentage of normal spacing was observed at the lower displacement speed for the seed dispensers, DB, DC, and DD. These seed dispensers also showed higher productivity as compared to other seed dispensers.

Keywords: agronomic characters, longitudinal distribution, statistical process control, pneumatic meter.

Abbreviations: UCL_upper control limit; LCL_lower control limit; DA_seed dispenser A; DB_seed dispenser B; DC_seed dispenser C; DD_seed dispenser D; V1_velocity $1\left(7.0 \mathrm{~km} \mathrm{~h}^{-1}\right)$; V2_velocity $2\left(11.5 \mathrm{~km} \mathrm{~h}^{-1}\right)$.

\section{Introduction}

The maize crop has great economic important due to its high nutritional value and use in both human and animal food. With its potential to be inserted between crops for crop rotations makes it a good option for no-tillage agricultural systems (Bottega, et al., 2014). For such systems, the use of machines and equipment aims to improve operational capacity, facilitate manual work, and improve production efficiency. With the adoption of the no-tillage system, the greatest difficulty is to obtain seeders that meet the conditions of this management system (Trogelo et al., 2014). The sowing process requires adequate longitudinal distribution of seeds in the soil, combined with the correct deposition depth of seeds to obtain a sufficient and uniform plant population (Almeida et al., 2010). It is one of the steps that require perfection in their execution because it can compromise the profitability of agricultural activity (Ros et al., 2011). During mechanized sowing, several factors interfere with the establishment of plant stands and the production of culture. These parameter include the speed of the sowing rates, field capacity, speed of the seed dispenser, distance and depth of seeds, the occurrence of doubles, and mechanical damage (Garcia et al., 2011).
Among these parameters that effect sowing, seed dispensers stand out because of their ability to make a regular distribution of seed possible at variable work speeds and edaphoclimatic conditions. However, negative effects of working speeds on the performance of seeders has been observed both in cotton and in corn (Yazgi \& Degirmencioglu, 2014). In this context, the statistical process control is a promising option to evaluate agricultural activities involving mechanized operations. This follows from the fact that it can give a vision of how a certain process occurs over time while indicating possible failures and gateways for process improvements with the aim to enhance the quality of agricultural operations (Voltarelli et al., 2015). When investigating different seed distribution mechanisms with different technical, operational, and environmental conditions, it is assumed that average distance between plants is important; however, the average distance is not sufficient to assess the quality of sowing. The quantification and understanding of the occurrence of failed and duplicate plants in the sowing furrow is also imperative (Storck et al., 2015). This highlights the importance of the application of other tests, such as the evaluation of the process. 
The novelty of the work is the statistical analysis used here since it is a promising tool in the field of agricultural research, which allows monitoring of agricultural processes over time and space. The tools used in the process are control charts that facilitate the visualization of the process and help infer whether the process quality is satisfactory. Control charts are indicators of improvement in the quality of maize sowing. Therefore, the objective of this work was to evaluate the quality of corn sowing as a function of the seed dispensers used and their working speeds by means of the statistical control process.

\section{Results and discussion}

\section{Descriptive statistics}

The quality indicators, (i) depth of seeds and (ii) percentage of normal spacing, at the speed, $7.0 \mathrm{~km} \mathrm{~h}^{-1}$ for the seed dispensers, DB and DD, had a non-normal distribution in their data set as indicated by Ryan-Joiner test (Table 1).

It was found that the seed dispenser, DC, had the highest average percentage of normal spacing and plant population at V1 $\left(7.0 \mathrm{~km} \mathrm{~h}^{-1}\right)$; also, it exhibited higher productivity as compared to other seed dispensers, but this increased productivity was found at V2 $\left(11.5 \mathrm{~km} \mathrm{~h}^{-1}\right)$.

The seed dispenser, DA, at V2, and DC, at both $\mathrm{V} 1$ and $\mathrm{V} 2$, with their variable productivities showed higher values of asymmetry coefficient: $-1.09,1.54$, and 1.09 , respectively. Similarly, the seed dispenser, DB, at V2, and DD, at V1, had coefficient values of 1.02 and -2.22 , respectively, as compared to the percentage of normal spacing. This coefficient is used to characterize how much and in what way does the frequency distribution depart from skewness; the largest skewness values from zero have a skewness distribution to the right while values less than zero are skewed to the left, indicating the removal of the variability with respect to a central value.

As for the kurtosis coefficient, the parameters evaluated in all treatments showed values higher or lower than zero, which demonstrated that the behavior of the normal data curve was that of a platykurtic distribution, i.e., showed a flattened distribution curve for the data. The coefficients below zero showed a leptokurtic distribution curve and those above zero showed an elongated distribution curve with high coefficients of variation for most variables.

\section{Statistical quality control}

The control charts for the depth of seeds (Figure 1) and both the speeds were stable without the presence of points that lay out of control. For V1, the seed dispensers, DA and DC, showed little difference from the other seed dispensers, with lower variability in the process of sowing and lower average sowing depth of around 4 to $5 \mathrm{~cm}$. This lower variability in the seeding depth indicated a good quality of the sowing process and adequate deposition of seeds, thus improving the chances of quick germination.

Sowing of maize at depths of 6-to 8-cm depth provides quicker seed emergence and higher total seedling emergence (Silva et al., 2015). Among all the 4 seed dispensers, only DB acted at this depth, but it showed higher variability in the process, which is contrary to the other dispensers that sowed seeds at lower depths.
The depth of seeding (around $3.5 \mathrm{~cm})$ at V2 $\left(11.5 \mathrm{~km} \mathrm{~h}^{-1}\right)$ (Figure 1B) was noticeable for the seed dispenser, DC, as compared to the other seed dispensers due to lesser variability and higher stability of the process. As shown in Figure $1 \mathrm{~A}$ and $\mathrm{B}$ (for V1 and V2), with an increase in speed, a decrease in sowing depth occurred for all 4 seed dispensers analyzed here, but the process remained stable. On the contrary, Garcia et al. (2011) observed that an increase in speed from 2.5 to $4.4 \mathrm{~km} \mathrm{~h}^{-1}$ caused a $30.2 \%$ increase in seeding depth.

Figure 2 shows the distribution of normal spacings at both V1 and the V2 with the seed dispenser DC; although, there is lower variability, but both speeds led to points that lay out of control, and thus, indicated the process to be unstable. Such points can be attributed to special causes, such as the presence of imperfections in the ground that may lead to the seed dispensers performing incorrect distribution.

On comparing Figures $2 \mathrm{~A}$ and $\mathrm{B}$, it can be observed that although the seed dispenser, DC, has presented an unstable process, even at the lower speed, it showed a higher normal spacing percentage (73\%) and exemplified the best behavior of seed dispensers at lower speeds.

According to the control charts for the two speeds, it was noted that the increase in speed caused a decrease in the percentage of normal spacing for seed dispensers, DB, DC, and DD. Difference in the sowing speeds significantly influenced the uniformity of seed distribution, leading to failed spacing, the presence of double seeds, and reduction in acceptably sown seeds (Trogello et al., 2013).

At V1 (Figure 3A), the seed dispensers, DA, DC and DD, presented stable process with regard to the final plant population. The lowest variability was observed with the seed dispenser, DB, however, there were points that lay outside the control limits; these can be attributed to special causes. With the help of individual values on control charts, it can be checked whether or not extrinsic factors affect the process, and whether these factors are related to the $6 \mathrm{Ms}$ (material, manpower, method, machine, measurement, and mother Nature). In this way, this tool can provide certain information about the behavior of the seeding process (Voltarelli et al., 2013).

On the contrary from what was observed for final populations at V1 and V2 (Figure 3B) for other seed dispensers, the dispenser, DC, showed a lower variation indicating better quality of sowing process with an average final population of around 42,700 plants per hectare.

As shown in Figures $3 \mathrm{~A}$ and $\mathrm{B}$ for speeds $\mathrm{V} 1$ and $\mathrm{V} 2$, it is clear that with increasing speeds, there was a greater variability in the final plant population. Melo et al. (2014) worked with displacement speeds in the continuous flow seeder to report an influence of speed on both the depth of seed deposition and plant density.

The seed dispenser, DA, showed better performance in relation to productivity at V1 because it showed a stable process with less variability (Figure 4A); the average productivity was around $7500 \mathrm{~kg} \mathrm{ha}^{-1}$, There was only a little difference between in productivity at the two speeds and with seed dispenser, DC and DD. Furlani et al. (2013) found that the displacement speed was not statistically different with values ranging between 6.1 and $6.4 \mathrm{~km} \mathrm{~h}^{-1}$; this is near the recommended speeds for seeder-fertilizer with pneumatic-type seed dispenser. 
Table 1. Descriptive statistics for sowing quality indicators as a function of seed dispensers and different working speeds.

\begin{tabular}{|c|c|c|c|c|c|c|c|c|}
\hline Seed dispenser & Speeds & Variables & Mean & $\sigma$ & VC & Cs & $\mathrm{Ck}$ & RJ \\
\hline \multirow{8}{*}{ DA } & $7.0 \mathrm{~km} \mathrm{~h}^{-1}$ & Seed depth & 3.75 & 1.001 & 19.15 & 0.04 & 2.93 & $0.99^{N}$ \\
\hline & $11.5 \mathrm{~km} \mathrm{~h}^{-1}$ & $(\mathrm{~cm})$ & 3.49 & 1.093 & 31.28 & -0.04 & -1.09 & $0.99^{N}$ \\
\hline & $7.0 \mathrm{~km} \mathrm{~h}^{-1}$ & & 41.49 & 12.4 & 29.75 & 0.12 & 0.32 & $0.98^{\mathrm{N}}$ \\
\hline & $11.5 \mathrm{~km} \mathrm{~h}^{-1}$ & $\%$ normal spacing & 47.45 & 11.5 & 24.23 & 0.07 & -0.77 & $0.98^{\mathrm{N}}$ \\
\hline & $7.0 \mathrm{~km} \mathrm{~h}^{-1}$ & & 41944 & 4186 & 9.98 & 0.46 & -0.86 & $0.97^{N}$ \\
\hline & $11.5 \mathrm{~km} \mathrm{~h}^{-1}$ & Plant population & 42000 & 4020 & 9.57 & 0.84 & -1.08 & $0.98^{\mathrm{N}}$ \\
\hline & $7.0 \mathrm{~km} \mathrm{~h}^{-1}$ & & 6938 & 1329 & 19.15 & 0.57 & 0.98 & $0.95^{N}$ \\
\hline & $11.5 \mathrm{~km} \mathrm{~h}^{-1}$ & Productivity (kg ha-1) & 7942 & 2363 & 29.75 & -1.09 & 1.15 & $0.97^{\mathrm{N}}$ \\
\hline \multirow{8}{*}{ DB } & $7.0 \mathrm{~km} \mathrm{~h}^{-1}$ & Seed depth & 3.31 & 0.678 & 20.44 & 0.42 & 2.12 & $0.96^{\mathrm{A}}$ \\
\hline & $11.5 \mathrm{~km} \mathrm{~h}^{-1}$ & $(\mathrm{~cm})$ & 3.5 & 1.07 & 30.72 & -0.67 & 0.33 & $0.99^{N}$ \\
\hline & $7.0 \mathrm{~km} \mathrm{~h}^{-1}$ & & 65.69 & 15.44 & 23.5 & -0.35 & -0.38 & $0.98^{N}$ \\
\hline & $11.5 \mathrm{~km} \mathrm{~h}^{-1}$ & $\%$ normal spacing & 55.17 & 13.43 & 24.34 & -1.02 & 2.13 & $0.96^{\mathrm{A}}$ \\
\hline & $7.0 \mathrm{~km} \mathrm{~h}^{-1}$ & & 43889 & 3922 & 8.94 & -0.75 & 1.44 & $0.98^{\mathrm{N}}$ \\
\hline & $11.5 \mathrm{~km} \mathrm{~h}^{-1}$ & Plant population & 41667 & 3655 & 8.77 & 0.24 & -0.89 & $0.99^{\mathrm{N}}$ \\
\hline & $7.0 \mathrm{~km} \mathrm{~h}^{-1}$ & & 7346 & 1512 & 20.59 & -0.02 & 0.2 & $0.99^{N}$ \\
\hline & $11.5 \mathrm{~km} \mathrm{~h}^{-1}$ & Productivity (kg ha-1) & 7063 & 1544 & 21.86 & 0.69 & -0.55 & $0.96^{\mathrm{N}}$ \\
\hline \multirow{8}{*}{ DC } & $7.0 \mathrm{~km} \mathrm{~h}^{-1}$ & Seed depth & 3.31 & 0.678 & 20.44 & 0.42 & -0.47 & $0.98^{\mathrm{N}}$ \\
\hline & $11.5 \mathrm{~km} \mathrm{~h}^{-1}$ & $(\mathrm{~cm})$ & 3.503 & 1.076 & 30.72 & 0.33 & -0.67 & $0.99^{\mathrm{N}}$ \\
\hline & $7.0 \mathrm{~km} \mathrm{~h}^{-1}$ & & 72.69 & 12.49 & 17.18 & -0.28 & -0.58 & $0.99^{N}$ \\
\hline & $11.5 \mathrm{~km} \mathrm{~h}^{-1}$ & $\%$ normal spacing & 54.42 & 12.9 & 23.71 & 0.36 & 1.08 & $0.98^{\mathrm{N}}$ \\
\hline & $7.0 \mathrm{~km} \mathrm{~h}^{-1}$ & & 43944 & 3749 & 8.53 & -0.5 & -0.41 & $0.99^{N}$ \\
\hline & $11.5 \mathrm{~km} \mathrm{~h}^{-1}$ & Plant population & 42722 & 3431 & 8.03 & 0.22 & -1.14 & $0.99^{\mathrm{N}}$ \\
\hline & $7.0 \mathrm{~km} \mathrm{~h}^{-1}$ & & 7793 & 14.61 & 18.75 & 1.54 & 4.17 & $0.93^{\mathrm{A}}$ \\
\hline & $11.5 \mathrm{~km} \mathrm{~h}^{-1}$ & Productivity $\left(\mathrm{kg} \mathrm{ha}^{-1}\right)$ & 7979 & 1610 & 20.18 & -1.09 & 1.6 & $0.95^{\mathrm{N}}$ \\
\hline \multirow{8}{*}{ DD } & $7.0 \mathrm{~km} \mathrm{~h}^{-1}$ & Seed depth & 4.58 & 1.16 & 25.41 & -0.4 & -0.67 & $0.98^{N}$ \\
\hline & $11.5 \mathrm{~km} \mathrm{~h}^{-1}$ & $(\mathrm{~cm})$ & 4.425 & 1.17 & 26.36 & 0.07 & -0.35 & $0.99^{\mathrm{N}}$ \\
\hline & $7.0 \mathrm{~km} \mathrm{~h}^{-1}$ & & 71.08 & 18.58 & 26.14 & -2.28 & 6.9 & $0.87^{\mathrm{A}}$ \\
\hline & $11.5 \mathrm{~km} \mathrm{~h}^{-1}$ & $\%$ normal spacing & 59.38 & 12.89 & 21.71 & -0.01 & 0 & $0.99^{\mathrm{N}}$ \\
\hline & $7.0 \mathrm{~km} \mathrm{~h}^{-1}$ & & 43611 & 3210 & 7.36 & 0.01 & 0.26 & $0.99^{N}$ \\
\hline & $11.5 \mathrm{~km} \mathrm{~h}^{-1}$ & Plant population & 41611 & 4666 & 11.21 & -0.89 & 0.17 & $0.99^{\mathrm{N}}$ \\
\hline & $7.0 \mathrm{~km} \mathrm{~h}^{-1}$ & & 7628 & 1238 & 16.23 & 0.38 & -0.3 & $0.96^{\mathrm{N}}$ \\
\hline & $11.5 \mathrm{~km} \mathrm{~h}^{-1}$ & Productivity (kg ha-1) & 7882 & 2020 & 25.63 & 0.6 & 0.22 & $0.98^{\mathrm{N}}$ \\
\hline
\end{tabular}

$\sigma$, standard deviation; VC (\%), Variation coefficient; Cs, skewness coefficient; Ck, kurtosis coefficient; DA, DB, DC, DD, different seed dispensers; RJ, Ryan-Joiner normality test (N, normal distribution; A, non-normal distribution).

A

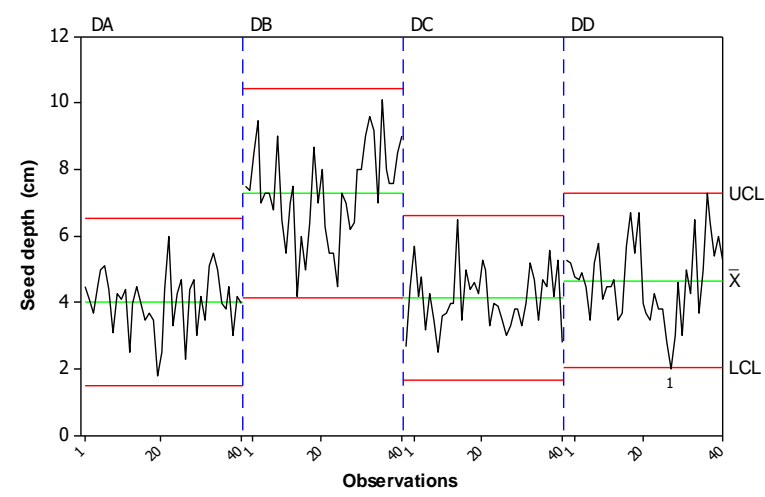

B

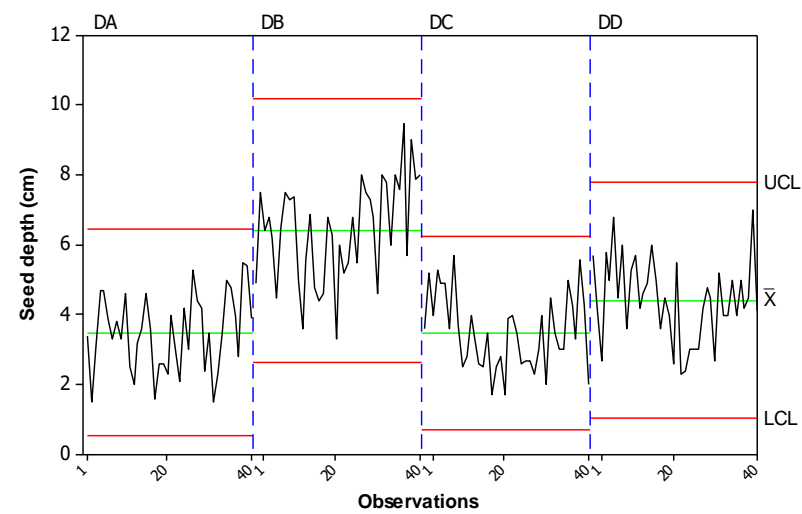

Fig 1. Individual values on control charts for seed depth of corn for the 4 seed dispensers at the two speeds. Points that are out of bounds (in red lines) are considered to lie out of control. V1 $=7.0 \mathrm{~km} \mathrm{~h}^{-1}(\mathrm{~A})$ and V2 $=11.5 \mathrm{~km} \mathrm{~h}^{-1}(\mathrm{~B})$. UCL, upper control limit; LCL, lower control limit; $X$, arithmetic mean. 
A

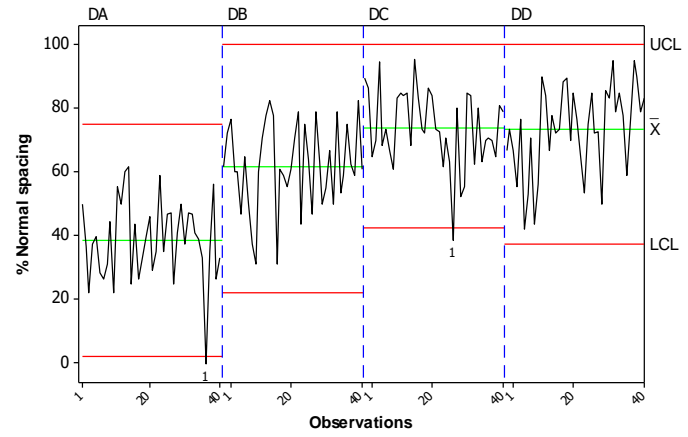

B

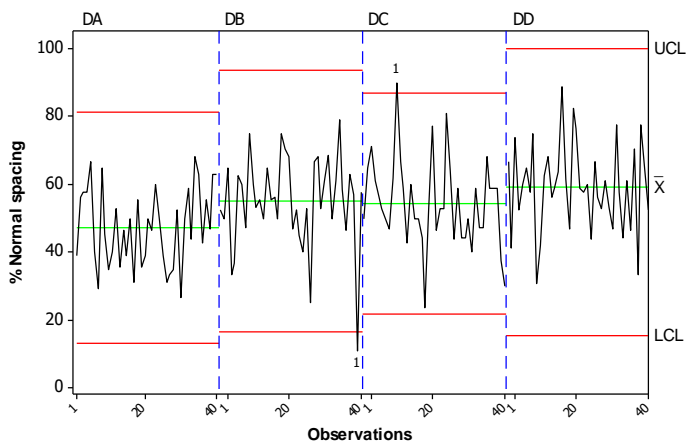

Fig 2. Individual values on control charts for $\%$ normal spacing of corn for the 4 seed dispensers at the two speeds. Points that are out of bounds (in red lines) are considered to lie out of control. V1 $=7.0 \mathrm{~km} \mathrm{~h}^{-1}(\mathrm{~A})$ and V2 $=11.5 \mathrm{~km} \mathrm{~h}^{-1}(\mathrm{~B})$. UCL, upper control limit; LCL, lower control limit; X, arithmetic mean.

A

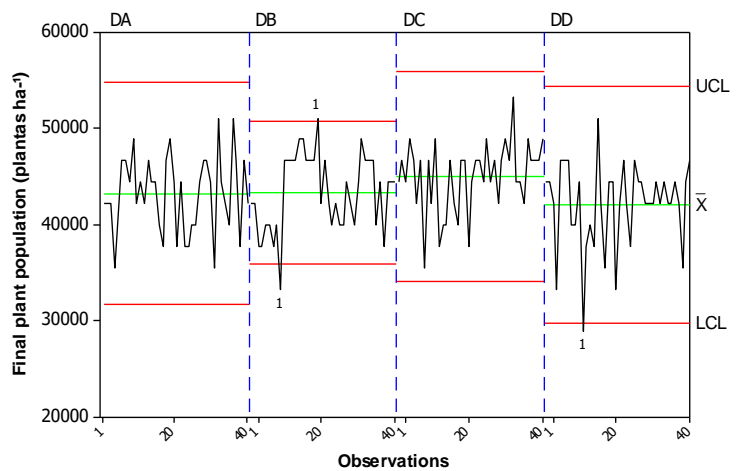

B

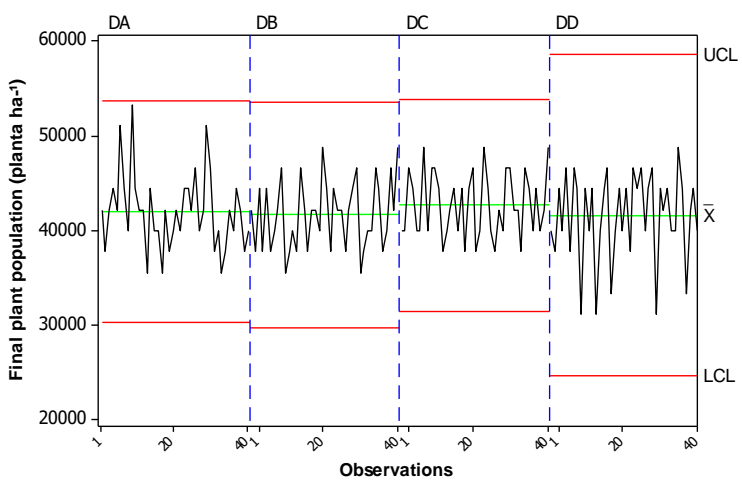

Fig 3. Individual values on control charts for the final plant populations of corn for the 4 seed dispensers at the two speeds. Points that are out of bounds (in red lines) are considered to lie out of control. V1 $=7.0 \mathrm{~km} \mathrm{~h}^{-1}$ (A) and V2 $=11.5 \mathrm{~km} \mathrm{~h}^{-1}$ (B). UCL, upper control limit; LCL, lower control limit; X, arithmetic mean. 
A

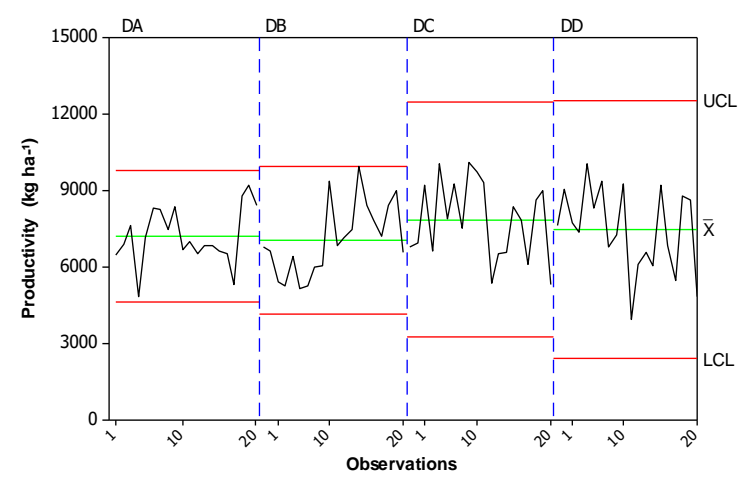

B

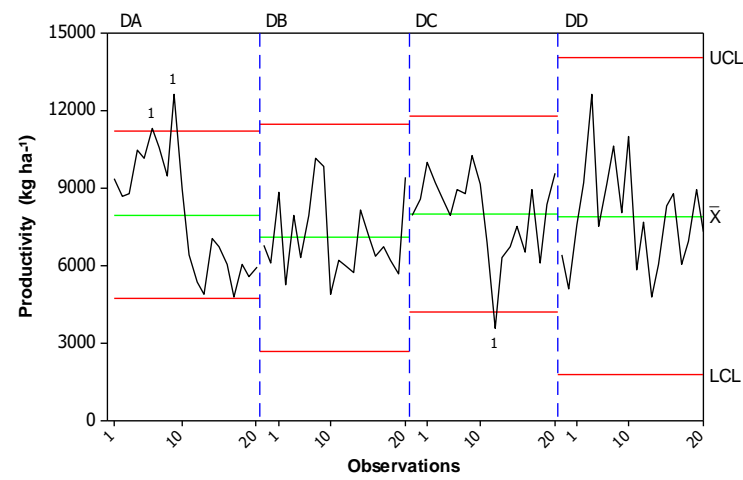

Fig 4. Individual values on control charts for the productivity of corn for the 4 seed dispensers at the two speeds. Points that are out of bounds (in red lines) are considered to lie out of control. V1 $=7.0 \mathrm{~km} \mathrm{~h}^{-1}(\mathrm{~A})$ and V2 $=11.5 \mathrm{~km} \mathrm{~h}^{-1}$ (B). UCL, upper control limit; $\mathrm{LCL}$ : lower control limit; $\mathrm{X}$, arithmetic mean.

In case of productivity, the seed dispenser, DA, showed a lower variability in the data at both the speeds, V1 and V2, but at higher speeds, there were more points that lay outside of the control, i.e., the process became unstable. This can be attributed to special causes as already mentioned. The lowest speed exhibited better process quality. In an experiment with corn using different seed dispensers and working speeds, Miller et al. (2012) found no difference in the agronomic parameters that were evaluated at speeds below $8 \mathrm{~km} \mathrm{~h}^{-1}$ in any of the seed dispensers. However, at speeds above $11.3 \mathrm{~km} \mathrm{~h}^{-1}$ to $14.5 \mathrm{~km} \mathrm{~h}^{-1}$, the distribution units showed a negative effect on plant spacing.

\section{Materials and methods}

\section{Experimental conditions}

The experiment was conducted in an agricultural area on a farm in the state of São Paulo located around the geodetic coordinates, $21^{\circ} 14^{\prime} 54$ "S and $48^{\circ} 16^{\prime} 51^{\prime \prime} \mathrm{W}$, with an average altitude of $568 \mathrm{~m}$ and an average slope of $4 \%$. The soil in the area is classified as an Oxisol with a clayey texture and undulated relief (Santos et al., 2013). The culture of corn (Zea mays L.) was planted in an area that had been undergoing a no-tillage system for 13 years using the variety, hybrid 30F35YH.

We used the tractor, Massey Ferguson Model MF 7370125 kW (170 hp), with a rotational speed of $2000 \mathrm{rpm}$, used to test a prototype of the seeder, Jumil 3070 pneumatic model Exacta Air. This seeder consisted of 4 seeding units and 4 different seed dispensers, resulting in 4 rows sown with a spacing of $0.90 \mathrm{~m}$.
The seed dispenser was constructed with 28 -hole discs. In the seed dispenser, DA, both its overall structure and seed discs were built of a polymer called polyacetal. This seed dispenser was attached to a seeder unit on which the tests were conducted. The seed disks rotated counterclockwise. In the seed dispenser, DB, there was a distributor made of aluminum with plastic discs, which rotated counterclockwise; this dispenser had more robust chassis for heavier seeding. In the seed dispenser, DC, aluminum distributors and plastic discs were present with stronger chassis for heavier seeding; also, in this dispenser, the direction of rotation was clockwise. In the seed dispenser, DD, simple and light chassis, aluminum distributors, and plastic discs were present with a counterclockwise rotation.

\section{Quality indicators}

The quality indicators tested for mechanized sowing of corn were:

- Sowing depth, which is the depth of deposition of corn seeds, was measured by means of manual digging. In this method, furrows dug during the sowing process were carefully excavated with the aid of a knife so as not to move the seed. A ruler was then used to measure the depth at which the seed has been deposited in the furrow. In this manner, 5 seeds per plot were tested in the presence of an evaluator for better control of the experimental conditions. - Longitudinal distribution of seeds: This indicator was measured by counting the number of seedlings according to the method of Kurachi et al. (1989). The mentioned level of uniformity was acceptable spacing on the percentages situated between 0.5 and $1.5 \mathrm{~cm}$ compared to the reference 
spacing of each seedlings. Initial and final plant populations were determined by counting the number of corn plants per plot, considering the useful area. Grain yield was evaluated by manual harvesting of crop within the useful area in each plot $\left(4.5 \mathrm{~m}^{2}\right)$ with subsequent threshing of corn. After weighing the grains, the recorded data (grams per plot) was converted to $\mathrm{kg} \mathrm{ha}^{-1}$. The values thus obtained were corrected for $13 \%$ water content.

\section{Experimental design and statistical analysis}

All evaluations were performed based on the quality control methodology described previously (Montgomery, 2009). Forty sampling points were evaluated for each treatment that were for the four seed dispensers from the different manufacturers denoted, $D A, D B, D C$, and $D D$, at two working speeds (V1 $=7,0 \mathrm{~km} \mathrm{~h}^{-1}$ and $\left.\mathrm{V} 2=11,5 \mathrm{~km} \mathrm{~h}^{-1}\right)$. The points were collected in lines sowed by each seed dispenser, delimiting a useful area of $5 \mathrm{~m}$ around each point that was spaced 10 meters. The general trend in the data was identified by descriptive statistical analysis by calculating a measure of central tendency (average), two measures of dispersion (standard deviation and variation coefficient), two asymmetric measures (asymmetry coefficient and kurtosis coefficient), and by performing the Ryan-Joiner test for normality. The latter provided a measure of proximity of the points and estimated the probability straight, giving greater validity to the analysis (Aldor-Noiman et al., 2013).

The results were also evaluated using the statistical process control, which employed control charts of individual values with central lines (overall average) and lines indicating the upper and lower limits of statistical control abbreviated as UCL and LCL. These limits were calculated based on the standard deviation of the variables (for UCL, averaged over three times the standard deviation; and LCL, averaged less than three times the deviation, when greater than zero) (Montgomery, 2009).

\section{Conclusion}

The seed dispenser, DC, showed a higher number of quality indicators to lie within the control limits during the sowing process. The lower speed of work, i.e., $7 \mathrm{~km} \mathrm{~h}^{-1}$, showed better quality, i.e., less variability of the monitored quality indicators. The highest percentage of normal spacings was found at the lower displacement speed for the seed dispensers DB, DC, and DD, these seed dispensers also showed higher productivity as compared to other seed dispensers. The statistical process control offers an interesting and reliable means to evaluate the quality of the sowing process, and thus, has the potential to help producers solve specific problems related to possible failures that may occur during agricultural operations.

\section{References}

Aldor-Noiman SA, Brown LD, Stine RA (2013) The power to see: A new graphical test of normality. Am Stat. 67: 249-260.

Almeida RAS, Tavares-Silva CA, Silva SL (2010) Desempenho energético de um conjunto trator-semeadora em função do escalonamento de marchas e rotações do motor. Agrarian. 3: 63-70.
Bottega EL, Rosolem DH, de Oliveira Neto AM, Piazzetta VLH, Guerra N (2014) Qualidade da semeadura do milho em função do sistema dosador de sementes e velocidades de operação. Global Science and Technology. 7: 107-114.

Furlani CEA, Canova R, Cavichioli FA, Bertonha RS, Silva RP (2013) Demanda energética por semeadora-adubadora em função da haste sulcadora na semeadura do milho. Revista Ceres. 60: 885-889.

Garcia RF, Vale WG, Oliveira TR, Pereira EM, Amim TCB (2011) Influência da velocidade de deslocamento no desempenho de uma semeadora-adubadora de precisão no Norte Fluminense. Acta Sci Agron. 33: 417-422.

Kurachi SAH, Costa JAS, Bernardi JA, Coelho JLD, Silveira GM (1989) Avaliação tecnológica de semeadoras e/ou adubadoras: tratamento de dados de ensaios e regularidade de distribuição longitudinal de sementes. Bragantia. 48: 24962.

Melo RP, Fernandes FRB, Nascimento HCF, Maia CL, Albiero D (2014) Análise do controle de qualidade da densidade de distribuição de arroz por uma semeadora de fluxo contínuo. Revista Brasileira de Engenharia de Biossistemas. 8: 343-350.

Miller EA, Rascon J, Koller A, Porter WM, Taylor R, Raun WR (2012) Evaluation of corn seed vacuum metering systems. Paper presented at the American Society of Agricultural and Biological Engineers Annual International Meeting. 1: 815825.

Montgomery DC (2009) Introduction to statistical quality control. 6th edn. Wiley, Arizona. 734p.

Ros VV, Souza CMA, Vitorino ACT, Rafull LZL (2011) Oxisol resistence to penetration in no-till system after sowing. Eng Agríc. 31: 1104-1114.

Santos HG, Jacomine PKT, Anjos LHC, Oliveira VA, Lumbreras JF, Coelho MR, Almeida JA, Cunha TJF, Oliveira JB (2013) Sistema brasileiro de classificação de solos (3ed) Embrapa, Brasília. 353p.

Silva PRA, Dias PP, Correia TPS, Sousa SFG (2015) Emergencia de plântulas de milho em diferentes profundidades de semeadura. Irriga. 1: 178-185.

Storck L, Modolo AJ, Brum B, Trogello E, Franchin MF, Adami PF (2015) Medida de regularidade do espaçamento de plantasbde milho em diferentes sistemas de manejo. Rev bras eng agríc ambient. 19(1): 39-44, 2015.

Trogello E, Modolo AJ, Dallacort R, Baesso MM, Scarsi M (2014) Desenvolvimento do milho sobre diferentes manejos de palhada, sulcadores e velocidades de semeadura. Rev Bras Milho Sorgo. 13: 142-153.

Trogello E, Modolo AJ, Scarsi M, Dallacort R (2013) Manejos de cobertura, mecanismos sulcadores e velocidades de operação sobre a semeadura direta da cultura do milho. Bragantia. 72: 101-109.

Voltarelli MA, Silva RP, Rosalen DL, Zerbato C, Cassia MT (2013) Quality of performance of the operation of sugarcane mechanized planting in day and night shifts. Aust J Crop Sci. 7: 1396-1406.

Voltarelli MA, Silva RP, Zerbato C, Silva VFA, Paixão CSS (2015) Monitoring of losses in the process of mechanical harvesting tomato. Revista Engenharia na Agricultura. 23: 315-325.

Yazgi A, Degirmencioglu A (2014) Measurement of seed spacing uniformity performance of a precision metering unit as function of the number of holes on vacuum plate. Measurement. 56: 128-135. 